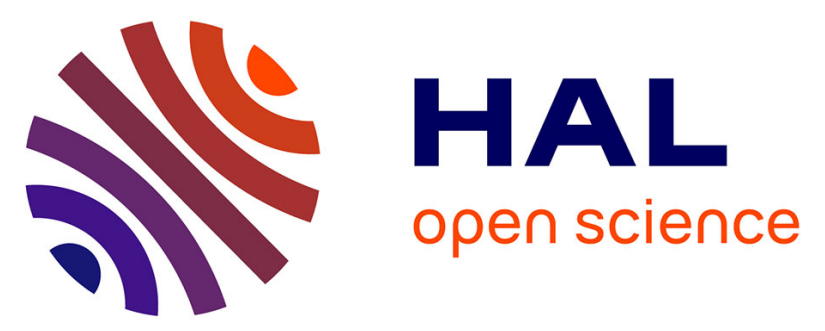

\title{
Floral organogenesis and morphogenesis of [italic]Staphisagria[/italic] (Ranunculaceae): Implications for the evolution of synorganized floral structures in Delphinieae
}

Julie Zalko, Samuel Frachon, Antoine Morel, Thierry Deroin, Felipe Espinosa, Kun-Li Xiang, Wei Wang, Wen-Gen Zhang, Simon Lang, Lara Dixon, et al.

\section{To cite this version:}

Julie Zalko, Samuel Frachon, Antoine Morel, Thierry Deroin, Felipe Espinosa, et al.. Floral organogenesis and morphogenesis of [italic]Staphisagria[/italic] (Ranunculaceae): Implications for the evolution of synorganized floral structures in Delphinieae. International Journal of Plant Sciences, 2020, 10.1086/711471 . hal-02975177

\section{HAL Id: hal-02975177 \\ https://hal.science/hal-02975177}

Submitted on 22 Oct 2020

HAL is a multi-disciplinary open access archive for the deposit and dissemination of scientific research documents, whether they are published or not. The documents may come from teaching and research institutions in France or abroad, or from public or private research centers.
L'archive ouverte pluridisciplinaire HAL, est destinée au dépôt et à la diffusion de documents scientifiques de niveau recherche, publiés ou non, émanant des établissements d'enseignement et de recherche français ou étrangers, des laboratoires publics ou privés. 


\section{Floral organogenesis and morphogenesis of Staphisagria (Ranunculaceae): Implications}

\section{for the evolution of synorganized floral structures in Delphinieae}

Julie Zalko ${ }^{1}$, Samuel Frachon ${ }^{1}$, Antoine Morel $^{1}$, Thierry Deroin ${ }^{1}$, Felipe Espinosa ${ }^{1}$, Kun-Li Xiang ${ }^{2,3}$, Wei Wang ${ }^{2,3}$, Wen-Gen Zhang ${ }^{4}$, Simon Lang ${ }^{5}$, Lara Dixon ${ }^{6}$, Myreya Pinedo-Castro ${ }^{7}$, Florian Jabbour ${ }^{1, *}$

${ }^{1}$ Institut de Systématique, Evolution, Biodiversité (ISYEB), Muséum national d'Histoire naturelle, CNRS, Sorbonne Université, EPHE, Université des Antilles, CP39, 57 rue Cuvier, 75005 Paris, France; ${ }^{2}$ State Key Laboratory of Systematic and Evolutionary Botany, Institute of Botany, Chinese Academy of Sciences, Beijing 100093, China; ${ }^{3}$ University of Chinese Academy of Sciences, Beijing 100049, China; ${ }^{4}$ Forestry College, Jiangxi Agricultural University, Nanchang 330045, China; ${ }^{5}$ Muséum national d'Histoire naturelle, DGD MJZ, Banque de graines du MNHN, 57 rue Cuvier, 75005 Paris, France; ${ }^{6}$ Conservatoire botanique national méditerranéen de Porquerolles, 34 avenue Gambetta, 83400 Hyères, France;

${ }^{7}$ Laboratorio de Genética de Poblaciones Molecular-Biología Evolutiva, Departamento de Biología, Facultad de Ciencias, Pontificia Universidad Javeriana, Cra 7ª No. 43-82, Bogotá DC, Colombia

* Author for correspondence; e-mail: fjabbour@mnhn.fr.

Shortened title: The hyperorgan of Delphinieae

Keywords: Delphinieae, nectar spur, perianth, petal fusion, Staphisagria, synorganization 


\begin{abstract}
Premise of the research. Floral synorganization is a structural feature of many speciose angiosperm taxa, and is considered as a morphological innovation paving the way for evolutionary diversification. Staphisagria is sister to the remaining Delphinieae, the only lineage of Ranunculaceae characterized by zygomorphic flowers. We aim at providing a description of floral organogenesis and morphogenesis in both Staphisagria species, presenting the disparity of Delphinieae hyperorgan in a phylogenetic framework, and proposing a scenario of likely developmental pathways underlying the different types of hyperorgans in Delphinieae.

Methodology. We carried out morphological, anatomical, and developmental studies on flowers of Staphisagria macrosperma and S. picta.
\end{abstract}

Pivotal results. Synorganization is complex in Staphisagria and Delphinieae as a whole, and involves flower dorsoventralization, nesting of spurs, postgenital fusion of petals, and the formation of a shared cavity. From a choripetalous ancestor, late and partial postgenital fusion among dorsal petals evolved once or twice in the tribe.

Conclusions. Delphinieae flower includes nested spurs and nested floral parlors. These key innovations, unique in angiosperms, probably led to the diversification of this species-rich tribe in the Northern Hemisphere. The length of the inner (nectariferous) spurs and the nested floral parlors determine the range of pollinators able to collect nectar. These traits could be used to revise the circumscription of taxonomic groups within the tribe, and should be taken into account when examining the possible coevolution between Delphinieae flowers and their pollinators. Integrating this new knowledge about the hyperorgan will be essential for future research in taxonomy, evo-devo and pollination ecology in Delphinieae. 


\section{Introduction}

Floral synorganization is a structural feature of many speciose angiosperm taxa, and is considered as a morphological innovation paving the way for evolutionary diversification (Endress 2011). Although the term synorganization was coined by a zoologist in 1952 (Remane 1952), the concept did not spread much within this community (but see SalviniPlawen and Splechtna 1979; Wagner 1989). However, it thrived quite early in botany (Vogel 1959, 1969), and its definition has been successively amended by floral morphologists (Endress 1990; Erbar 1991; Verbeke 1992; Specht and Bartlett 2009; Endress 2010a; Ronse De Craene 2010; Ley and Claßen-Bockhoff 2012; Endress 2016; Sokoloff et al. 2018). Building on these works, we would define the concept as follows:

Synorganization is the macroscopic integration and close spatial association of two or several neighboring structural elements or ancestrally independent organs, with or without fusion. Regarding function, the product of synorganization is not simply the sum of the parts, rather the elaboration of a complex functional unit or hyperorgan. Regarding evolution, a hyperorgan is a morphological - sometimes key - innovation. Structures can only be considered as synorganized in a taxon comparatively with non-synorganized homologous structures in the sister taxon.

Synorganized floral parts have been described in a wide range of angiosperm lineages (Endress 1990, 2010b). In Ranunculales, the earliest-diverging order of eudicots (APG IV 2016), synorganization was briefly reported in the flowers of the tribe Delphinieae, in which the nectar spurs of the dorsal petals are nested within the hollow dorsal sepal (Chartier et al. 2016; Chen et al. 2018; Jabbour et al. in press). The phylogenetic position of Delphinieae within Ranunculaceae, and the floral morphological evolution in the family were both 
clarified recently (Zhai et al. 2019; Carrive et al. 2020). Phylogenetic relationships within Delphinieae have been largely clarified as well in the last ten years (Jabbour and Renner 2011b, 2012b; Wang et al. 2013; Espinosa et al. 2017; Hong et al. 2017; Xiang et al. 2017).

The Delphinieae calyx is zygomorphic and consists of one dorsal, two lateral, and two ventral sepals. The corolla is dorsoventralized (hence zygomorphic) and generally comprises four developed petals in dorsal position. The two dorsalmost are spurred and nectariferous, and the pair of petal spurs is nested within the spur or hood of the dorsal sepal (for more details about Delphinieae floral organization, see Jabbour and Renner 2012a). Floral morphology in Delphinieae has been the object of numerous studies, mostly focusing on spurred petal morphology and development (Payer 1857; Kosuge and Tamura 1988, 1989; Erbar et al. 1998; Jabbour et al. 2009; Jabbour and Renner 2012a; W. Zhang et al. unpublished manuscript). According to Endress (2001) a spur is a hollow outgrowth of a laminar organ. Anatomical aspects of nectar production in Delphinieae start to be better understood (Antoń and Kamińska 2015). In order to describe the nectariferous hyperorgan development and structure, we focus on the genus Staphisagria Hill, which is sister to all the other Delphinieae. The name Staphisagria (Hill 1756) refers to the similarity of the leaves with leaves of wild

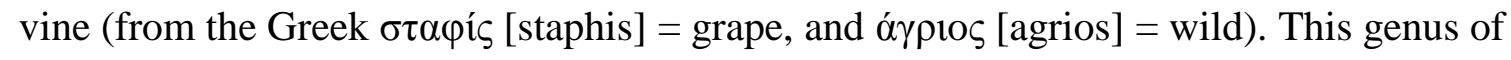
Mediterranean plants consists of a pair of species, S. macrosperma Spach and S. picta (Willd.) Jabbour, according to Aboucaya (1989) and Léotard (2002; this MSc thesis became available to us in 2018), the latter having synonymized S. requienii (DC.) Spach with S. picta, based on multivariate analyses of morphological traits. Staphisagria macrosperma is widely distributed in the Mediterranean Basin, except in Libya and Egypt. In contrast, S. picta is endemic to Corsica, Sardinia, Mallorca and Hyères islands (Léotard 2002; Orellana 2008; Tison and de Foucault 2014). The traditional use of S. macrosperma seeds as a cure for diverse ailments 
(Bruneton 1995) might explain its widespread occurrence, and the very contrasted distribution areas of both species called for investigations of their respective genetic diversity (Orellana et al. 2009a, 2009b).

Our objective is two-fold:

1) Provide a thorough description of floral organogenesis and morphogenesis in both Staphisagria species, focusing on the development of the hyperorgan.

2) In a recently updated phylogenetic framework (Espinosa et al. 2017; Hong et al. 2017; Xiang et al. 2017), and for each of the constitutive genera of Delphinieae, namely Staphisagria Hill, Aconitum L., Gymnaconitum (Stapf) Wei Wang \& Z.D.Chen and Delphinium L., present the morphological diversity of the hyperorgan, and propose a scenario of likely developmental pathways and molecular bases possibly underlying the different types of hyperorgans in Delphinieae.

\section{Material and Methods}

\section{Sampling}

Young inflorescences and flower buds from both Staphisagria species were sampled from living plants, and samples were fixed with FAA (90\% ethanol 70\%, 5\% formalin, 5\% acetic acid) for 24 hours, and stored in a mixture of water, ethanol and glycerol in equal volumes. Plants were grown in the Mediterranean greenhouse (four individuals of S. macrosperma sampled in April-May 2019) and in the garden of the MNHN seed bank, and in the garden of the MNHN École de Systématique (many individuals of S. picta sampled in May 2015, June 2016, and May 2017). Seeds were provided by the MNHN seed bank (S. picta, \# accession 08-38, collected in 1986 in Porquerolles (France)), or were sent by the Conservatoire botanique national méditerranéen de Porquerolles (S. macrosperma, \# accession M 7145 Lyo $3141^{*}$, collected in 1992 in Flassans-sur-Issole (Var, France); S. picta, \# accession M 
16358 - 1992 B7, collected in 1992 in Calenzana (Corsica, France); \# accession M 6531 Lyo 1017, collected in 1991 in Le Brégançonnet (Porquerolles island, France)).

Plants from both species are kept as herbarium specimens at Paris Herbarium $(\mathrm{P})$; barcodes for S. macrosperma are P04023428 and P04023429, and for S. picta are P04023155 and P04023156. High-resolution images can be downloaded from P online public database (https://science.mnhn.fr/institution/mnhn/collection/p/item/search/form).

For the anatomical study, flowers were taken from the following herbarium specimens: P02345181 (S. macrosperma, one flower) and P00249055 (S. picta, two flowers). As the anatomical study was carried out long before the flowering of S. macrosperma plants, we could not rely on fresh material for both species, hence we had to sample buds from herbarium specimens.

To investigate the evolution and development of the Delphinieae hyperorgan in a phylogenetic framework, we chose the well-studied genus Nigella as a representative of Nigelleae, the sister group of Delphinieae (Zhai et al. 2019). Nigella, and especially Nigella damascena, has been intensively studied regarding the development and evolution of its perianth (Zhao et al. 2011; Gonçalves et al. 2013; Zhang et al. 2013; Deroin et al. 2015; Jabbour et al. 2015; Wang et al. 2015; Damerval and Becker 2017; Damerval et al. 2018; Yao et al. 2019; Liao et al. 2020; F. Jabbour et al. unpublished manuscript). Because nectariferous petals originated once within Ranunculaceae (Carrive et al. 2020), petals in Nigelleae and Delphinieae are homologous.

\section{Scanning electron microscopy observations}

A total of about 200 floral buds for each of the Staphisagria species were dissected using a stereoscope (Nikon SMZ 745T). They were dehydrated in an ethanol series $(70 \%, 80 \%$, absolute alcohol) and dried using an Emitech K850 critical point dryer (Quorum 
Technologies), then mounted on aluminum stubs with colloidal graphite, sputter coated with carbon (60 seconds of metallization) using a EM ACE600 fine coater (Leica), and observed using a SU3500 scanning electron microscope (Hitachi).

\section{Restoration of herbarium material and anatomical sections}

One preanthetic floral bud was sampled from a herbarium specimen for each of the species $S$. macrosperma and S. picta. They were restored in an ammoniacal $10 \%$ aq. solution at $60^{\circ} \mathrm{C}$ during 24 hours, then fixed with FAA for 24 hours, and finally stored in a mixture of water, ethanol and glycerol in equal volumes.

Buds were dehydrated through a t-butyl series and embedded in paraffin (melting point: 58$\left.60{ }^{\circ} \mathrm{C}\right)$ (Gerlach 1984). Serial transverse sections were cut at a thickness of $12 \mu \mathrm{m}$ using a rotary microtome (Leitz 1512 , Germany), then stained with AstraBlue $0.5 \%$ aq. $\left(\right.$ Chroma ${ }^{\circledR} 1 \mathrm{~B}$ $163)$ and Ziehl's Fuchsine $\left(\right.$ RAL $\left.^{\circledR} 320490-1000\right)$ 10\% aq. and mounted in the mounting medium Eukitt (O.Kindler $\mathrm{GmbH}^{\circledR}$ E0214). Mounted material was observed using Zeiss Axioskop microscope. Samples are kept at the plant histology micro-slide library at Paris Herbarium (P; https://www.mnhn.fr/en/collections/collection-groups/botany/histothequehistology-library).

\section{Results}

\section{Floral organogenesis and outer/inner spur length ratio}

In both Staphisagria species, floral organs initiate centripetally following an ontogenic spiral. Spiral phyllotaxis is most obvious in the calyx (quincuncial aestivation of the five petaloid sepals; fig. 1A) and in the androecium (c. 40 stamen primordia organized in parastichies; fig. $1 B, 1 C, 1 E, 1 F)$. Petal primordia (most generally eight) initiate after sepals and before stamens. Their development stops soon after initiation, and continues again once carpel 
primordia initiate (fig. $1 B, 1 D-1 F$ ). Floral organogenesis is completed when the three free carpels (fig. $1 C, 1 E-1 H$ ) are initiated. Zygomorphy is established after floral organogenesis is completed, through the dorsoventralization of the corolla (fig. 1D): the four dorsal petals develop and differentiate (the two dorsalmost petals get spurred) while the four ventral ones remain at a rudimentary developmental stage, and are very often not noticeable at anthesis. Unicellular trichomes with swollen base are formed on the abaxial side of sepals when stamen primordia initiate (fig. $1 B, 1 C$ ).

Flowers open and mature on the raceme in an acropetal sequence. In the S. macrosperma and S. picta plants we cultivated, outer spur (borne on the dorsal sepal) length is $c .2 .3 \mathrm{~mm}$ and 9 $\mathrm{mm}$, respectively, and inner spur (borne on each of the dorsalmost petals) length is $c .5 .8 \mathrm{~mm}$ and $7 \mathrm{~mm}$, respectively (fig. $1 I-1 L$ ). The ratios outer/inner spur length are hence 0.4 and 1.3 , respectively, and while the outer spur of $S$. macrosperma is four times shorter than that of $S$. picta, inner spurs are of similar lengths in both species. The outer spur is generally bifid in both species (fig. $1 K, 1 L$ ), but this feature is mostly visible in $S$. picta flowers (fig. $1 L$, and P04023155 herbarium specimen). Lateral petals have a narrow claw and a dilated lamina.

Petal morphogenesis: late partial postgenital fusion and parallel formation of notch and spur The corolla of Staphisagria consists of four dorsal petals and four ventral petals (fig. $2 A-2 J$ ). Front, lateral and upside-down views of the corolla show that the four dorsal petals are the only ones to develop and grow. All four dorsal petals are bilobed (fig. $2 B-2 D, 2 G-2 J$ ) and are characterized by the formation of a basal ridge, the height of which corresponds to the height of the fusion among the four petals (fig. $2 G-2 J$ ). Each of the two dorsalmost petals is basally and laterally fused to the other dorsalmost petal and to the adjacent dorsolateral petal (fig. $2 G-2 J$ ), and fusion occurs at a late developmental stage, i.e. long after organogenesis is completed and during carpel morphogenesis. Ventral petals tend to become triangular in 
shape as development proceeds (fig. $2 B, 2 D, 2 E-2 J$ ). In teratological cases in S. picta (c. $2 \%$ of the dissected floral buds), the two dorsalmost petal primordia fuse at a very early developmental stage, generating a single dorsalmost organ, flanked by dorsolateral petals (fig. $2 K, 2 L)$. In rare cases, we observed partial fusions among adjacent ventral petals, and noted that ventral primordia developed into a thin stalk of petaloid tissue.

Hollow outgrowths are formed abaxially in the two dorsalmost petals (fig. $2 G-2 J$ ). These outgrowths are not located at the exact middle of the dorsal petal limbs. Rather, they are displaced towards the dorsal pole of the flower (fig. $2 G-2 I$ ). This is especially visible on the two dorsalmost petals (fig. 2I). The dorsolateral petals remain relatively flat, in spite of developing also a ridge (fig. $2 G-2 J$ ), while the dorsalmost petals get spurred (fig. $2 I$ ). In the latter petals, the formation of the spur parallels that of the notch, and the pair of dorsalmost petals with deep notches facing each other creates a shared cavity (fig. $3 A-3 G$ ). At the stage when hairs develop on the upper limit of the notch, the opposite side of the petal limb becomes winged (fig. $3 F$ ). Spur formation in the petals precedes that in the dorsal sepal (fig. $3 H-3 J$ ), and both inner spurs grow equally (fig. $3 K$ ).

\section{All dorsal petals are nectariferous}

The anatomical sections of the flower of S. macrosperma show that the tip of the outer spur is bifid (fig. 4A), and that the spurs of the two dorsalmost petals are nested within the spur of the sepal (fig. 4B). Results for S. picta (not shown) are identical. The basal union of the four dorsal petals is shown in fig. $4 C-4 E$. The four dorsalmost petals are nectariferous (fig. $4 B$, $4 G-4 H$ ). The inner epidermis of the spur is covered with large cells colored in red (fig. $4 B$ ). Nectariferous tissue was found as well in the dorsalmost petals at the floor of the shared cavity (fig. 4G), hence relatively close to spur entrance, and at the inner epidermis of the pits of the dorsolateral petals (fig. $4 H$ ). 


\section{Discussion}

The complexity of Staphisagria hyperorgan

Staphisagria hyperorgan consists of a pair of spurs nested in a third one. The spurred dorsal petals are nectariferous, basally fused, and share a common cavity at spur entrance. The investigation of flower development was key to identify the different structures involved in the formation of the hyperorgan. Flower development in Staphisagria is similar to that in Delphinium (Jabbour et al. 2009; Chang et al. 2019; W. Zhang et al. unpublished manuscript). Five sepal quincuncially initiate, and the development of eight petal primordia (exceptionally nine, fig. $2 F$ ) stops soon after initiation. This developmental delay observed in petals is common in Ranunculaceae (Payer 1857; Jabbour et al. 2009; Zhao et al. 2011, 2012) and is also a feature of other plant families (Payer 1857; Sattler 1973).

In a first stage, the four dorsal petals develop in a similar way, and exhibit an adaxial basal ridge (growing into a scale). A small hollow depression is delimited adaxially by this scale and abaxially by the petal labium. In the postgenitally and basally fused dorsal petals, the height of the fused tissue does not exceed the position of the scales. Basal connation is always observed between the two dorsalmost petals, and often observed between three out of the four dorsal petals, the unfused one being the eighth initiated petal (not the seventh), so the farthest spatially to the dorsalmost ones on the ontogenic spiral. In rare cases, only the pair of dorsalmost petals were basally fused.

In a second stage, the hollow depression between the scale and the labium gets deeper in the two dorsalmost petals, leading to the formation of spurs on the abaxial side of the labium. In a third stage, the dorsal sepal gets spurred, and this outer spur includes the pair of inner spurs. Our measurements for outer spur length (S. macrosperma: $2.3 \mathrm{~mm}$, and S. picta: $9 \mathrm{~mm}$ ) are in agreement with those of Léotard (2002) who reported, based on a much larger 
sampling, that outer spur length was on average $3.3 \mathrm{~mm}([2 ; 4.5]$, standard deviation (s.d.) $=$ $0.8)$ and $7.7 \mathrm{~mm}([4.5 ; 11.3]$, s.d. $=1.1)$, for $S$. macrosperma and S. picta, respectively. The fourth and last stage corresponds to the inner and outer spur growth and to the resupination of the dorsolateral petals (fig. 1I, and fig. 2D in Jabbour and Renner 2011a). During spur development, each of the two dorsalmost petals becomes notched, and both notches facing each other form a cavity shared by both petals. This observation was already illustrated by Payer (1857), analyzing floral development in S. picta (https://digi.ub.uniheidelberg.de/diglit/payer1857bd2/0067/image).

Anatomical investigation of preanthetic Staphisagria flowers revealed that nectariferous tissues were present on the inner epidermis of the inner spurs as shown in other Delphinieae taxa (Kosuge and Tamura 1988; Erbar et al. 1998; Antoń and Kamińska 2015), but secretory tissues were also found at the floor of the shared cavity (hence at the entrance of the spur) and on the inner epidermis of the small hollow depression in each of the dorsolateral petals. In the three flowers investigated, the four dorsal petals contain secretory tissues. This is an interesting finding as dorsolateral petals are usually regarded in the Delphinieae as having a role in attracting the pollinators and acting as a landing platform. Kosuge and Tamura (1988) already noted that in Ranunculaceae, nectar could be secreted and stored in small and not-sodeep cavities at the adaxial surface of the petal labium.

Hyperorgan organization in Delphinieae is unique among angiosperms, as it possesses a pair of nectariferous spurs included in a third hollow structure. Other flowering plant taxa present pairs of spur, but they are not nested within an outer spur (e.g. Satyrium Sw., Orchidaceae), or not nectariferous (Diascia Link \& Otto, Scrophulariaceae). 
This is our second attempt to categorize Delphinieae hyperorgan. Compared with the first one (Jabbour and Renner 2012a), in addition to the number, arrangement (e.g. nested spurs) and broad shape of organs involved, we consider here the basal fusion among the dorsal petals and the presence of notches on the dorsalmost petals. This high level of synorganization is uncommon in angiosperms, where it is thought to be low in flowers with spiral phyllotaxis (Endress 1990).

Three categories of hyperorgan can be distinguished in Delphinieae when considering the morphology and arrangement of the pair of dorsalmost petals and of the dorsal sepal (fig. 5). We here define three hyperorgan categories:

(1) the "Delphinium" type $-c .300$ species - two notched, basally-fused nectar spurs included in an outer spur. This type is found in Staphisagria and Delphinium subg. Delphinium, D. subg. Anthriscifolium (W.T.Wang) Wei Wang, D. subg. Delphinastrum (DC.) Peterm., and D. subg. Oligophyllon Dimitrova (following the classifications of Malyutin (1987) and Xiang et al. (2017)). Basal fusion of the two inner spurs was observed on many type specimens (suppl. fig. 1, note 1). Taxa with the shortest outer spur (Staphisagria), and the longest (D. leroyi Franch. ex Huth, suppl. fig. 2), are included in this category. More investigations are needed to determine the proportion of taxa from the "Delphinium" type for which dorsolateral petals are nectariferous and/or basally postgenitally fused (note 1, suppl. fig. 1) and/or resupinated (W. Zhang et al. unpublished manuscript).

(2) the "Consolida" type $-c .60$ species - a single nectar spur included in an outer spur or in a hood-shaped dorsal sepal. The inner spur results from the total postgenital fusion of the two dorsalmost petal primordia. This type is found in D. subg. Consolida (DC.) Gray (P.-E. Du Pasquier et al. unpublished manuscript).

(3) the "Aconitum" type - c. 300 species - two nectar spurs borne on long stalks included in a hood-shaped dorsal sepal, which can be more (A. subg. Lycoctonum (DC.) Peterm.) or less (A. 
subg. Aconitum, A. subg. Galeata (Rapaics) Y.Hong \& Q.E.Yang, A. subg. Fletcherum (Tamura) Y.Hong \& Q.E.Yang) basally constricted, and more (the subgenera just cited hereabove) or less (Gymnaconitum) covering the inner structures.

The shared cavity of Delphinieae hyperorgan could be considered as a floral parlor sensu Leppik (1964). According to Leppik, a parlor "is a reception room for floral visitors in a zygomorphic flower. It has a landing place, entrance, guiding signs to nectar deposits and other accommodations for welcomed visitors. But it is frequently closed for unwanted visitors". Regarding Aconitum flower, he adds: "Although the monkshood flower is open to all insects, not all visitors in the parlor can locate and reach the nectar deposits hidden in coiled nectaries". We foresee that the lateral and ventral sepals, and the dorsolateral petals all participate in shaping the entrance of the flower, being a broader floral parlor leading to the parlor of the dorsal petals (suppl. fig. 3).

Flowers of Delphinieae basically consist of nested spurs (spur(s) of the dorsal petal(s) included in the spur or hood of the dorsal sepal) and nested floral parlors. The first, and most obvious floral parlor, is the one that is created by the notches of the dorsalmost petals facing each other in the flowers from the "Delphinium" type. Both dorsal spurs seem there to create a single hollow structure. In the "Consolida" type, the dorsal spur is indeed a single hollow structure, which does not result from a notching that would extend to the tip of the spur, rather from the postgenital fusion of the pair of dorsal petal primordia. The second floral parlor is the one generated by the ventral and lateral sepals, and by the dorsolateral petals, arranged in such a way that they form a cup imposing a certain movement to the visitor, and this in melittophilous, sphingophilous and ornithophilous flowers.

Delphinieae flowers, especially those from the "Aconitum" and "Consolida" types, show a tubular organization, due to this second floral parlor. However, and in contrast with 
sympetalous flowers (Endress 2001), the sexual organs in Delphinieae are not located down the tube, but at the entrance of the tube. In addition, floral tubes in sympetalous flowers end in the floral base, which has a robust architecture, while floral spurs usually have no reinforced end (Endress 2001). This is not the case in Delphinieae, as the inner spurs might be protected by the outer spur or hood from herbivores or from large variations in temperature and humidity.

Characterizing in further details the disparity of Delphinieae hyperorgan would require to consider the shape of all perianth parts, the relative proportions of the notch length, the inner and outer spur length, and the position of the nectariferous tissue. The limit is now of taxonomic nature, and although small subclades of Delphinieae were recently revised (Staphisagria (Jabbour and Renner 2011a), A. subg. Lycoctonum (Hong et al. 2017), Gymnaconitum (Wang et al. 2013), D. subg. Delphinium (Du Pasquier et al. study under way), D. subg. Anthriscifolium (W. Zhang et al. unpublished manuscript), D. subg. Consolida (P.-E. Du Pasquier et al. unpublished manuscript)), the species-rich A. subg. Aconitum, D. subg. Delphinastrum and D. subg. Oligophyllon are still in need of important taxonomic (and nomenclatural) reevaluation. This taxonomic work that is still to be undertaken will necessarily have to characterize traits that have never been included in descriptions and keys so far (Huth 1895; Davis 1965; Munz 1967), namely, the length of inner spurs and the length of the notch on the inner spurs. Staphisagria macrosperma is known as the species with the shortest outer spur in the tribe Delphinieae (D. leroyi is the one with the longest outer spur, suppl. fig. 2, Johnson 2001; Chartier et al. 2016). While this is true for the outer spur, inner spurs are not exceptionally short in this species. The inner spurs are the structures that likely coevolve with the pollinators and that should be considered as being highly taxonomically discriminant. 
The function of Delphinieae hyperorgan is likely a combination of attraction, rewarding, and protection of visitors and pollinators. It appeared possible that the cavity shared by the spurred petals (the floral parlor) could serve as a shelter for small insects (FJ, pers. obs.; suppl. fig. 2), probably also feeding on nectar. Studies about the pollination ecology of Delphinieae flowers are not scarce (e.g. Macior 1975; Bosch et al. 1997; Johnson 2001; Liao et al. 2007; Wang et al. 2017; Jacquemart et al. 2019), and provide solid bases for future investigations that will have to integrate the morphological features analyzed here above.

\section{Possible evolutionary trends and developmental pathways}

We here discuss the evolution of Delphinieae hyperorgan, and propose a developmental scenario leading to the diversity of floral organizations observed in this tribe. The evolutionary and developmental scenarios presented here are updated versions of those presented by Jabbour and Renner (2012a) and Jabbour et al. (2009), respectively. The hypothetical common ancestor of Nigelleae and Delphinieae likely had a bipartite perianth consisting of petaloid sepals and $c .8$ nectariferous and free petals, and its floral organs were arranged following a spiral phyllotaxis. In the lineage leading to Delphinieae, a major developmental change occurred, viz. calyx and corolla dorsoventralization, leading to zygomorphic flowers. All flowers of Delphinieae lack ventral petals at the adult stage (although four petal primordia are initiated ventrally). Around half of the species within the tribe have four dorsal petals (two dorsalmost spurred, and two dorsolateral), the other half of the species have only one pair of developed petals, in dorsal position. Due to the topology of the tree resulting from the most recent phylogenetic studies, the ancestor of Delphinieae could have had two or four dorsal petals (both options equally parsimonious).

In few cases (c. 60 species in D. subg. Consolida (P.-E. Du Pasquier et al. unpublished manuscript)), flowers are tremendously reduced in size and organ number, and present only a 
single petal, resulting from the postgenital fusion of the two dorsalmost petal primordia (Jabbour and Renner 2012a; Chang et al. 2019). In marginal cases, flowers are peloric and lack a corolla at the adult stage (D. turcicum, in D. subg. Delphinium: Espinosa et al. 2017; D. ecalcaratum, in D. subg. Anthriscifolium: Ding et al. 1981; W. Zhang et al. unpublished manuscript).

The evolutionary trend towards petal fusion (generally basal, but total in the subgenus Consolida) in Delphinieae is to be highlighted, as fusion among floral organs is often linked with the presence of whorls (Endress 2001; Endress and Doyle 2009).

Flowers in Ranunculales show no or partial postgenital fusion (Endress and Doyle 2009). In Ranunculaceae, fusion among floral organs is recorded mostly in gynoecium (Hoot 1991; Endress and Doyle 2009). Based on the most recent phylogenetic framework available for Delphinieae, late and partial postgenital fusion evolved once (with a reversion to choripetaly in each of the lineages leading to Aconitum and Gymnaconitum) or twice (in each of the lineages leading to Staphisagria and Delphinium) in the tribe, and both scenarios are equally parsimonious. In Delphinium, postgenital fusion even became total (and early) in the lineage leading to $D$. subg. Consolida (fig. 5). This is not the first report of fusion among the dorsal petals in Staphisagria and Delphinium (Verlaque and Aboucaya 2001; Jabbour and Renner 2012a), and a study on an exhaustive sampling of Delphinieae is required to investigate the degree and timing of petal fusion (e.g. postgenital early in D. subg. Consolida, postgenital late in Staphisagria).

Additionally, anatomical investigations are required to document the diversity of nectariferous tissue location within the Delphinieae corolla, and to check whether secretory tissues are found not only in the inner epidermis of the spurs, but also at the floor of the shared cavity and in the small hollow cavity at the base of the dorsolateral petals. These findings will be pivotal to revise our ideas about pollinators' behavior when foraging for 
nectar in a Delphinieae flower. If spur length coevolves with the pollinators, this coevolution may not be as tight as expected (see Whittall and Hodges 2007; Vlašánková et al. 2017), as the inner spurs would not filter as strongly for the pollinators able to reach the nectar. In addition, in Delphinieae, the developmental background of the coordinated dorsal petal and dorsal sepal deformation still has to be investigated, using for instance floral mutants lacking corolla.

Genes involved in floral zygomorphy, petal fusion, and nectar spur development have been characterized in some species, that could fuel a candidate gene approach for deciphering the genetic origin of the nectariferous hyperorgan of Delphinieae. As for zygomorphy, the recurrent recruitment of CYCLOIDEA-like genes in various taxa has been observed (for review, Hileman 2014). In Ranunculaceae, $C Y C$-like genes have been characterized in various species including many Delphinieae (Jabbour et al. 2014). Two paralogous gene lineages have been found in the family with an additional duplication in each $C Y C$-like lineage in the Delphinieae ancestor. The expression of $C Y C$-like genes during floral development of selected Delphinieae species reveals species- and organ/stage-specific patterns, suggesting post-duplication species-specific subfunctionalisation (Jabbour et al. 2014). Functional analyses are required to assess the morphogenetic roles of these paralogs. Boundary genes that establish delimitation between meristems and organs and between organs by repressing growth can be considered good candidates for the evolution of petal fusion. The NAM/CUC3 subfamily of the NAC-domain transcription factor family has been especially investigated but with variable results in the different eudicot species studied to date (Rebocho et al. 2017; Preston et al. 2019; Phillips et al. 2020). The involvement of KNOX genes in the formation of ectopic outgrowths on the corolla tube has been demonstrated in Antirrhinum majus L. (Plantaginaceae), making these genes possible candidates for spur formation (Golz et al. 2002). Indeed, $K N O X$ genes appear involved in spur formation in the related species Linaria 
vulgaris Mill. (Box et al. 2011). In contrast, there is no evidence of a role of $K N O X$ genes in the development of the spurs in the Ranunculaceae genus Aquilegia L. that has evolved spurs independently from the Plantaginaceae (Yant et al. 2015). In the latter, the role of a member of the TCP transcription factor family, TCP4 and of auxin-related genes have been strongly suspected (Yant et al. 2015). Indeed, two AUXIN RESPONSIVE FACTOR genes, ARF6 and $A R F 8$ have recently been shown to promote cell elongation and the maturation of the nectary during spur formation in Aquilegia coerulea E.James (Zhang et al. 2020). In this species and in contrast with core eudicots where a role of the $Y A B B Y$ gene $C R A B S C L A W$ has been found (Lee et al. 2005), nectary formation seems to involve genes of the STYLISH transcription factor gene family (Min et al. 2019). Interestingly expression of STY1 has been observed in the spurred petals of Delphinium exaltatum Aiton and of the Berberidaceae Epimedium grandiflorum C.Morren, that are independent cases of nectariferous spur evolution in the Ranunculales (Min et al. 2019).

Zygomorphy, partial petal fusion, presence of spurs and nectaries are all floral traits that are highly homoplastic among angiosperms, and it is worth underlining that candidate approaches addresses the concepts of deep homology and/or of evolutionary tinkering from a toolkit of transcription factors and pathways. Increasing knowledge about the origin of these homoplasious traits are of great interest for understanding constraints and prospects in floral evolution.

\section{Conclusions}

Floral synorganization is highly complex in Staphisagria, and involves flower dorsoventralization, nesting of spurs, postgenital fusion of petals, and the formation of a shared cavity possibly disrupting the tight coevolutionary relationship between these spurred flowers and their pollinators that has been so far hypothesized. The disparity of the 
Delphinieae hyperorgan was discussed in a phylogenetic framework, and likely developmental pathways leading to the diversity of floral phenotypes were proposed. The flower of Delphinieae includes nested spurs and nested floral parlors, and these key innovations, unique in angiosperms, probably led to the diversification of this species-rich tribe in the Northern Hemisphere. We expect our study to inspire research in the fields of taxonomy, evo-devo, and pollination ecology.

Note 1 Species of Delphinium for which there is evidence that dorsalmost petals are notched and basally fused, and that a scale and a hollow depression can be found at the base of dorsolateral petals. Species name, barcode of the type specimen kept at P Herbarium, specification whether the notch and the basal fusion (indicated by a scar) of dorsalmost petals $\left({ }^{a}\right)$, and/or the scale of dorsolateral petals $\left({ }^{b}\right)$ are visible on the illustration found on the herbarium sheet (suppl. fig. 1). High-resolution images of the specimens can be accessed using the link: https://science.mnhn.fr/institution/mnhn/collection/p/item/search.

D. albiflorum, P00195724a, D. albocoeruleum, P00195731 $;$ D. altissimum, $\mathrm{P} 00195749^{\mathrm{b}} ;$ D. batangense, $\mathrm{P} 00195918^{\mathrm{ab}} ;$ D. caeruleum, P00197011 ${ }^{\mathrm{ab}} ;$ D. ceratophorum, $\mathrm{P} 00197081^{\mathrm{b}} ;$ D. chrysotricum, P00197116 $;$ D. hirticaule var. coelestinum, $\mathrm{P} 00197486^{\mathrm{b}} ;$ D. dasystachyon, P00197161 $;$; D. davidi, P00197163 ${ }^{\mathrm{b}} ;$ D. fargesii, $\mathrm{P} 00197304^{\mathrm{ab}} ;$ D. hirticaule var. hirticaule, P00197478 ${ }^{\mathrm{ab}} ;$ D. incisum, P00198623 ${ }^{\mathrm{ab}} ;$ D. lacostei, P00198649 ${ }^{\mathrm{ab}} ;$ D. lanigerum, P00198661 ${ }^{\mathrm{a}}$; D. lankongense, $\mathrm{P} 00198659^{\mathrm{b}} ;$ D. maackianum, $\mathrm{P} 00198688^{\mathrm{b}} ;$ D. maximoviczii, $\mathrm{P} 00198693^{\mathrm{b}}$; D. mosoynense, $\mathrm{P} 00198714^{\mathrm{ab}} ;$ D. oliganthum (determined as D. likiangense), $\mathrm{P} 00198675^{\mathrm{ab}} ; D$. orthocentrum, $\mathrm{P} 00198833^{\mathrm{a}} ;$ D. pachycentrum var. pachycentrum, $\mathrm{P} 00198837^{\mathrm{ab}} ; D$. penicillatum, P00198846 ${ }^{\mathrm{ab}} ;$ D. ponticum, P00195723 $;$ D. pylzowii, $\mathrm{P} 00198967^{\mathrm{ab}} ;$ D. quercetorum, $\mathrm{P} 00198968^{\mathrm{a}} ;$ D. siwanense, $\mathrm{P} 00198553^{\mathrm{ab}} ;$ D. souliei, $\mathrm{P} 00201009^{\mathrm{ab}} ;$ D. 
tatsienense, $\mathrm{P} 00201068^{\mathrm{b}} ;$ D. thibeticum var. subintegrum, $\mathrm{P} 00201112^{\mathrm{b}} ;$ D. trochophorum, P00201173ª, D. trifoliolatum, P00201192 ${ }^{\mathrm{ab}} ;$ D. tuberosum, P00201214 ${ }^{\mathrm{ab}} ;$ D. yunnanense, $\mathrm{P} 00201265^{\mathrm{ab}}$.

\section{Acknowledgements}

We acknowledge the MNHN seed bank and the MNHN Ecole de Systématique garden, the Plateau technique de microscopie électronique (UMR 7245 CNRS/MNHN; Géraldine Toutirais), and the Conservatoire botanique national méditerranéen de Porquerolles. The MNHN gives access to the collections in the framework of the RECOLNAT national Research Infrastructure. We thank Catherine Damerval for critical input on an earlier draft of the manuscript, Guillaume Léotard for providing his MSc thesis, Sonia Yakovlev for confirming the diploidy of S. picta, Andriy Novikov for taking the pictures of the transilluminated herbarium specimens, and Eugénie Carnero-Diaz and Isabel Le Disquet for taking pictures of the anatomical sections. We also thank Julie Kang (Editor) and two anonymous reviewers for their critical and helpful comments. This work was funded by the MNHN ATM (Action Transversale du Muséum) Blanche and by the Institute of Systematics, Evolution, Biodiversity (ISYEB) at the National Museum of Natural History, Paris. The field trip to Malawi was funded by the National Geographic Society (grant \#9989-16 to FJ).

\section{Literature Cited}

Aboucaya A 1989 La flore des îles d'Hyères: étude des rapports phytogéographiques et biosystématiques avec les Maures et la Corse (Doctoral dissertation, University AixMarseille 3).

Antoń S, M Kamińska 2015 Comparative floral spur anatomy and nectar secretion in four representatives of Ranunculaceae. Protoplasma 252:1587-1601. 
APG IV 2016 An update of the angiosperm phylogeny group classification for the orders and families of flowering plants: APG IV. Bot J Linn Soc 181:1-20.

Bosch M, J Simon, C Blanché, J Molero 1997 Pollination ecology in tribe Delphinieae (Ranunculaceae) in W Mediterranean area: Floral visitors and pollinator behaviour. Lagascalia 19:545-562.

Box MS, S Dodsworth, PJ Rudall, RM Bateman, BJ Glover 2011 Characterization of Linaria KNOX genes suggests a role in petal-spur development. Plant J 68:703-714.

Bruneton J 1995 Pharmacognosy, Phytochemistry, Medicinal Plants (2 ${ }^{\text {nd }}$ edition). Lavoisier publishing.

Carrive L, B Domenech, H Sauquet, F Jabbour, C Damerval, S Nadot 2020 Insights into the ancestral flowers of Ranunculales. Bot J Linn Soc In press.

Chang H, SR Downie, H Peng, F Sun 2019 Floral organogenesis in three members of the tribe Delphinieae (Ranunculaceae). Plants 8:493.

Chartier M, S Dressler, J Schönenberger, A Rojas Mora, C Sarthou, W Wang, F Jabbour 2016 The evolution of afro-montane Delphinium (Ranunculaceae): Morphospecies, phylogenetics and biogeography. Taxon 65:1313-1327.

Chen Y, F Jabbour, A Novikov, W Wang, S Gerber 2018 A study of floral shape variation in Delphinieae (Ranunculaceae) using geometric morphometrics on herbarium specimens. Bot Lett 165:368-376.

Damerval C, A Becker 2017 Genetics of flower development in Ranunculales-a new, basal eudicot model order for studying flower evolution. New Phytol 216:361-366.

Damerval C, W Ben Othman, D Manicacci, F Jabbour 2018 Distribution area of the two floral morphs of Nigella damascena L. (Ranunculaceae): A diachronic study using herbarium specimens collected in France. Bot Lett 165:396-403. 
Davis PH 1965 Flora of Turkey and the East Aegean islands, Vol 1. Edinburgh University Press, Edinburgh.

Deroin T, C Damerval, M Le Guilloux, F Jabbour 2015 Floral vascular patterns of the doubleflowered and wild-type morphs of Nigella damascena L. (Ranunculaceae). Mod Phytomorphol 7:13-20.

Ding BZ, SY Wang, ZY Gao 1981 Delphinium L. Pages 431-436 in Floral Henanensis, Vol.

1. Henan People's Publishing House, Zhengzhou. [In Chinese]

Endress PK 1990 Patterns of floral construction in ontogeny and phylogeny. Biol J Linn Soc 39:153-175.

- 2001 Origins of flower morphology. J Exp Zool 291:105-115.

2010a Synorganisation without organ fusion in the flowers of Geranium robertianum (Geraniaceae) and its not so trivial obdiplostemony. Ann Bot 106:687-695.

- $2010 b$ Flower structure and trends of evolution in eudicots and their major subclades. Ann Missouri Bot Gard 97:541-583.

2011 Evolutionary diversification of the flowers in angiosperms. Am J Bot 98:370396.

2016 Development and evolution of extreme synorganization in angiosperm flowers and diversity: A comparison of Apocynaceae and Orchidaceae. Ann Bot 117:749-767.

Endress PK, JA Doyle 2009 Reconstructing the ancestral angiosperm flower and its initial specializations. Am J Bot 96:22-66.

Erbar C 1991 Sympetaly - A systematic character? Bot Jahrb Syst 112:417-451.

Erbar C, S Kusma, P Leins 1998 Development and interpretation of nectary organs in Ranunculaceae. Flora 194:317-332.

Espinosa F, T Deroin, KL Xiang, W Wang, M Pinedo Castro, JW Byng, Z Aytaç, S Nadot, F Jabbour 2017 The Turkish endemic Pseudodelphinium turcicum (Ranunculaceae): An 
unusual population of Delphinium with peloric flowers that has persisted in the wild for 20 years. Int J Plant Sci 178:546-555.

Gerlach ZBD 1984 Botanische Mikrotechnik. Georg ThiemeVerlag, Stuttgart.

Golz JF, EJ Keck, A Hudson 2002 Spontaneous mutations in KNOX genes give rise to a novel floral structure in Antirrhinum. Curr Biol 12:515-522.

Gonçalves B, O Nougué, F Jabbour, C Ridel, H Morin, P Laufs, D Manicacci, C Damerval 2013 An APETALA3 homolog controls both petal identity and floral meristem patterning in Nigella damascena L. (Ranunculaceae) Plant J 76:223-235.

Hileman LC 2014 Trends in flower symmetry evolution revealed through phylogenetic and developmental genetic advances. Phil Trans R Soc B 369:20130348.

Hill J 1756 Genus XI. Stavesacre. Staphisagria. Page 44 in Osborne T, Shipton J, Hodges J, eds. The British herbal: An history of plants and trees, natives of Britain cultivated for use, or raised for beauty. Osborne and Shipton, London.

Hong Y, Y Luo, Q Gao, C Ren, Q Yuan, QE Yang 2017 Phylogeny and reclassification of Aconitum subgenus Lycoctonum (Ranunculaceae). PLoS ONE 12:e0171038.

Hoot SB 1991 Phylogeny of the Ranunculaceae based on epidermal microcharacters and macromorphology. Syst Bot 16:741-755.

Huth E 1895 Monographie der Gattung Delphinium. Bot Jahrb 20:322-499.

Jabbour F, G Cossard, M Le Guilloux, J Sannier, S Nadot, C Damerval 2014 Specific duplication and dorsoventrally asymmetric expression patterns of CYCLOIDEA-like genes in zygomorphic species of Ranunculaceae. PLoS ONE 9:e95727.

Jabbour F, SS Renner 2011a Resurrection of the genus Staphisagria J. Hill, sister to all the other Delphinieae (Ranunculaceae). Phytokeys 7:21-26. 
$2011 b$ Consolida and Aconitella are an annual clade of Delphinium (Ranunculaceae) that diversified in the Mediterranean basin and the Irano-Turanian region. Taxon 60:1029-1040.

$2012 a$ Spurs in a spur: Perianth evolution in the Delphinieae (Ranunculaceae). Int $\mathbf{J}$ Plant Sci 173:1036-1054.

$2012 b$ A phylogeny of Delphinieae (Ranunculaceae) shows that Aconitum is nested within Delphinium and that Late Miocene transitions to long life cycles in the Himalayas and southwest China coincide with bursts in diversification. Mol Phylogenet Evol 62:928-942.

Jabbour F, LP Ronse De Craene, S Nadot, C Damerval 2009 Establishment of zygomorphy on an ontogenic spiral and evolution of perianth in the tribe Delphinieae (Ranunculaceae). Ann Bot 104:809-822.

Jabbour F, M Udron, M Le Guilloux, B Gonçalves, D Manicacci, S Nadot, C Damerval 2015 Flower development schedule and AGAMOUS-like gene expression patterns in two morphs of Nigella damascena (Ranunculaceae) differing in floral architecture. Bot J Linn Soc 178:608-619.

Jabbour F, J Zalko, A Morel, S Frachon, I Bouchart-Dufay (in press) Ontogeny and evolution of the hyperorgan of Delphinieae. In Maurel MC, P Grandcolas eds. Systématique et exploration du vivant, ISTE Group.

Jacquemart AL, C Buyens, MF Hérent, J Quetin-Leclercq, G Lognay, T Hance, M Quinet 2019 Male flowers of Aconitum compensate for toxic pollen with increased floral signals and rewards for pollinators. Sci Rep 9:1-12.

Johnson SD 2001 Hawkmooth pollination and hybridization in Delphinium leroyi (Ranunculaceae) on the Nyika Plateau, Malawi. Nord J Bot 21:599-605. 
Kosuge K, M Tamura 1988 Morphology of the petal in Aconitum. Bot Mag Tokyo 101:223237.

1989 Ontogenetic studies on petals of the Ranunculaceae. J Jap Bot 64:65-74.

Lee JY, SF Baum, J Alvarez, A Patel, DH Chitwood, JL Bowman 2005 Activation of CRABS CLAW in the nectaries and carpels of Arabidopsis. Plant Cell 17:25-36.

Léotard G 2002 Étude morphologique de deux dauphinelles de Méditerranée occidentale : Delphinium pictum Willd. Delphinium requienii DC. (Ranunculaceae). Le statut spécifique de D. requienii est-il justifié ? (MSc dissertation, University Montpellier 2).

Leppik EE 1964 Floral evolution in the Ranunculaceae. Iowa State J Sci 39:1-101.

Ley AC, R Claßen-Bockhoff 2012 Floral synorganization and its influence on mechanical isolation and autogamy in Marantaceae. Bot J Linn Soc 168:300-322

Liao H, X Fu, H Zhao, J Cheng, R Zhang, X Yao, X Duan, H Shan, H Kong 2020 The morphology, molecular development and ecological function of pseudonectaries on Nigella damascena (Ranunculaceae) petals. Nature Commun 11:1-11.

Liao WJ, Z Wang, L Xie, W Xiao, Y Sun 2007 Floral advertisement and rewards in bumblebeepollinated Aconitum kusnezoffii (Ranunculaceae). Biodivers Sci 15:618-625.

Macior LW 1975 The pollination ecology of Delphinium tricorne (Ranunculaceae). Am J Bot 62:1009-1016.

Malyutin NI 1987 The system of the genus Delphinium (Ranunculaceae) based on the morphological features of seeds. Bot Zhurn (Moscow and Leningrad) 72:683-693.

Min Y, JI Bunn, EM Kramer 2019 Homologs of the STYLISH gene family control nectary development in Aquilegia. New Phytol 221:1090-1100.

Munz PA 1967 A synopsis of the Asian species of Delphinium, sensu stricto. J Arnold Arbor Harv Univ 48:249-302. 
Orellana MR 2008 Matapoll. Delphinium staphisagria. Planta del Mes 2008, núm. 3. Portal de Biologia de la Conservació de plantes. Laboratori de Botànica, Facultat de Farmàcia, Universitat de Barcelona. URI: http://hdl.handle.net/2445/20055

Orellana MR, C Blanché, J Simon, M Bosch 2009a Genetic diversity within and among disjunct populations of the Mediterranean island endemic Delphinium pictum and D. requienii (Ranunculaceae). Folia Geobot 44:47-63.

Orellana MR, J López-Pujol, C Blanché, AM Rovira, M Bosch 2009b Genetic diversity in Delphinium staphisagria (Ranunculaceae), a rare Mediterranean dysploid larkspur with medicinal uses. Genetica 135:221-232.

Payer JB 1857 Ordre des renonculacées : section des nigelles. Pages 247-252 in Traité d'organogénie comparée de la fleur. Masson, Paris.

Phillips HR, JB Landis, CD Specht 2020 Floral fusion: The evolution and molecular basis of a developmental innovation. J Exp Bot (In press)

Preston JC, B Powers, JL Kostyun, H Driscoll, F Zhang, J Zhong

2019 Implications of region-specific gene expression for development of the partially fused petunia corolla. Plant J 100:158-175.

Rebocho AB, JR Kennaway, JA Bangham, E Coen 2017 Formation and shaping of the Antirrhinum flower through modulation of the CUP boundary gene. Curr Biol 27:2610 2622.

Remane A 1952 Die Grundlagen des natürlichen Systems, der vergleichenden Anatomie und der Phylogenetik, Teil 1: Theoretische Morphologie und Systematik. Akademische Verlagsgesellschaft Geest \& Portig K.-G., Leipzig.

Ronse De Craene LP 2010 Floral diagrams: An aid to understanding flower morphology and evolution. Cambridge University Press, Cambridge. 
Salvini-Plawen VLV, H Splechtna 1979 Zur Homologie der Keimblätter. J Zool Syst Evol Res 17:10-30.

Sattler R 1973 Organogenesis of flowers. University of Toronto Press, Toronto.

Sokoloff DD, MV Remizowa, AC Timonin, AA Oskolski, MS Nuraliev 2018 Types of organ fusion in angiosperm flowers (with examples from Chloranthaceae, Araliaceae and monocots). Biol Serb 40:16-46.

Specht CD, ME Bartlett 2009 Flower evolution: the origin and subsequent diversification of the angiosperm flower. Annu Rev Ecol Evol Syst 40:217-243.

Tison JM, B de Foucault 2014 Flora gallica: flore de France. Biotope.

Verbeke JA 1992 Fusion events during floral morphogenesis. Annu Rev Plant Biol 43:583598.

Verlaque R, A Aboucaya 2001 Position des Delphinium du sous-genre Staphisagria dans la tribu des Delphinieae Warm (Ranunculaceae). Bocconea 13:189-200.

Vlašánková A, E Padyšáková, M Bartoš, X Mengual, P Janečková, Š Janeček 2017 The nectar spur is not only a simple specialization for long-proboscid pollinators. New Phytol 215:1574-1581.

Vogel S 1959 Organographie der Bluten kaplandischer Ophrydeen mit Bemerkungen zum Koaptationsproblem. Teil I Disinae und Satyriinae. Jahrb Akad Wiss Lit Abh MathNaturwiss K1 Mainz 6:270-401.

1969 Über synorganisierte Blütensporne bei einigen Orchideen. Plant Syst Evol 116:244-262.

Wagner GP 1989 The biological homology concept. Ann Rev Ecol Syst 20:51-69.

Wang P, H Liao, W Zhang, X Yu, R Zhang, H Shan, X Duan, X Yao, H Kong 2015 Flexibility in the structure of spiral flowers and its underlying mechanisms. Nat Plants 2:1-10. 
Wang W, Y Liu, SX Yu, TG Gao, ZD Chen 2013 Gymnaconitum, a new genus of Ranunculaceae endemic to the Qinghai-Tibetan Plateau. Taxon 62:713-722.

Wang LL, C Zhang, ML Yang, GP Zhang, ZQ Zhang, YP Yang, YW Duan 2017. Intensified wind pollination mediated by pollen dimorphism after range expansion in an ambophilous biennial Aconitum gymnandrum. Ecol Evol 7:541-549.

Whittall JB, SA Hodges 2007 Pollinator shifts drive increasingly long nectar spurs in columbine flowers. Nature 447:706-709.

Xiang KL, Z Aytaç, Y Liu, F Espinosa, F Jabbour, JW Byng, CF Zhang, AS Erst, W Wang 2017 Recircumscription of Delphinium subg. Delphinium (Ranunculaceae) and implications for its biogeography. Taxon: 66:554-566.

Yant L, S Collani, J Puzey, C Levy, EM Kramer 2015 Molecular basis for three-dimensional elaboration of the Aquilegia petal spur. Proc R Soc B 282:20142778.

Yao X, W Zhang, X Duan, Y Yuan, R Zhang, H Shan, H Kong 2019 The making of elaborate petals in Nigella through developmental repatterning. New Phytol 223:385-396.

Zhai W, X Duan, R Zhang, C Guo, L Li, G Xu, H Shan, H Kong, Y Ren 2019 Chloroplast genomic data provide new and robust insights into the phylogeny and evolution of the Ranunculaceae. Mol Phylogenet Evol 135:12-21.

Zhang R, C Guo, W Zhang, P Wang, L Li, X Duan, Q Du, L Zhao, H Shan, SA Hodges, EM Kramer, Y Ren, H Kong 2013 Disruption of the petal identity gene APETALA3-3 is highly correlated with loss of petals within the buttercup family (Ranunculaceae). Proc Natl Acad Sci 110:5074-5079.

Zhang R, Y Min, LD Holappa, CL Walcher-Chevillet, X Duan, E Donaldson, H Kong, EM Kramer 2020 A role for the Auxin Response Factors ARF6 and ARF8 homologs in petal spur elongation and nectary maturation in Aquilegia. New Phytol 227:1392-1405. 
Zhao L, JB Bachelier, HL Chang, XH Tian, Y Ren 2012 Inflorescence and floral development in Ranunculus and three allied genera in Ranunculeae (Ranunculoideae, Ranunculaceae). Plant Syst Evol 298:1057-1071.

Zhao L, P Liu, XF Che, W Wang, Y Ren 2011 Floral organogenesis of Helleborus thibetanus and Nigella damascena (Ranunculaceae) and its systematic significance. Bot J Linn Soc 166:431-443. 


\section{Figure captions}

Fig. 1 Developmental sequence of the floral meristem of Staphisagria. Sequences of both species are identical. SEM pictures with a black and white background were taken from $S$. macrosperma and S. picta buds, respectively. A, Floral meristem showing the quincuncial organization of the five sepals, at the stage of stamen initiation. The second (hence dorsal) sepal in the initiation sequence is at the bottom. $B$, Floral meristem at an equivalent developmental stage with the second, fourth and fifth sepals sectioned, showing the four dorsal petals (asterisks) and the first two primordia of each stamen parastichy. $C$, Floral meristem at the completion of organogenesis. Three carpel primordia initiate at the top of the meristem. $D, E, F$, Upside-down and two lateral views of the floral bud at successive developmental stages, showing the dorsal petals (asterisks) which development is delayed compared with the development of stamens and carpels. Ventral petals are indicated with arrowheads. $G$, Three free carpels. $H$, Longitudinal section of a carpel showing ovule placentation. I, Flower of S. macrosperma, with five petaloid sepals, two resupinated dorsolateral petals, the limb of which partly covers the sexual organs, and two dorsalmost petals. The tips of the spurs of the latter petals are nested in the spur of the dorsal sepal. $J, K$, Lateral and back view of a S. macrosperma flower, showing the tips of the spurs of the dorsalmost petals pointing upwards (arrows) in the bifid spur of the dorsal sepal. L, Flower of S. picta. Pet.: petal. Scale bars: A, $150 \mu \mathrm{m} ; \mathrm{F}, \mathrm{H}, 200 \mu \mathrm{m}$; B, C, D, E, $250 \mu \mathrm{m}$; G, $1 \mathrm{~mm}$; I, J, $\mathrm{K}, \mathrm{L}, 1 \mathrm{~cm}$.

Fig. 2 Developmental sequence of the corolla of Staphisagria. SEM pictures with a black and white background were taken from $S$. macrosperma and $S$. picta buds, respectively. $A, B, C$, $D$, upside-down and lateral views of successive developmental stages. $E, F, G, H, I, J$, Front views of successive developmental stages. $A, B$, Upside-down views of the floral meristem 
showing the dorsal (asterisks) and ventral (arrowheads) petals at successive developmental stages. Dorsal petals develop while ventral ones remain in a rudimentary developmental stage. $C$, lateral view showing four bilobed basally fused dorsal petals. Only two out of the four ventral petals are visible. $D$, Upside-down view of the floral meristem showing the dorsal (asterisks) and ventral (arrowheads) petals, at a stage when the dorsalmost petals get spurred. $E, F$, Front views of the corolla (all other floral organs removed) at successive developmental stages, showing the developing four dorsal petals. Note the five ventral petals (arrowheads) in $F . G, H, I, J$, Successive stages of the developing corolla. The bilobed, basally fused dorsal petals present a basal ridge. The limb of all of them shows a basal depression, which develops into a spur in the pair of dorsalmost petals. $K, S$. picta floral bud showing the pair of dorsalmost petal primordia getting fused. $L$, At a later stage, both dorsal petals are totally fused into a single four-lobed spade-like structure. Scale bars: E, K, L, $200 \mu \mathrm{m}$; A, C, F, 250 $\mu \mathrm{m} ; \mathrm{B}, \mathrm{D}, \mathrm{G}, \mathrm{H}, 500 \mu \mathrm{m} ; \mathrm{I}, \mathrm{J}, 1 \mathrm{~mm}$.

Fig. 3 Developmental sequence of one of the two dorsalmost petals and of the dorsal sepal of Staphisagria. SEM pictures with a black and white background were taken from $S$.

macrosperma and $S$. picta buds, respectively. $A, B, C, D, E, F$, Successive developmental stages of one of the two dorsalmost petals getting notched and spurred. Note the scars on both sides of the short stalk indicating basal fusion with the adjacent petals. In $F$, the arrowhead points at the hairs developping on the upper limit of the notch. $G$, View on the abaxial side of the pair of dorsalmost petals. The black and white arrows indicate the fusion of the stalks, and the width of the shared cavity, respectively. $H, I, J, K$, Successive developmental stages of one of the two dorsalmost petals in S. picta $(H, I, J$; including the dorsal sepal getting spurred) and $S$. macrosperma $(K)$. In $K$, although underdeveloped, one ventral petal is visible (arrowhead). Scale bars: A, B, C, $250 \mu \mathrm{m}$; D, E, H, I, $500 \mu \mathrm{m} ; \mathrm{F}, \mathrm{G}, \mathrm{J}, 1 \mathrm{~mm} ; \mathrm{K}, 2 \mathrm{~mm}$. 
Fig. 4 Transverse sections of a preanthetic floral bud of Staphisagria macrosperma, showing the anatomy of the floral structures. $A$, Transverse section of the bifid tip of the dorsal sepal spur. $B$, Transverse section of the dorsal sepal spur, closer to the floral receptacle, showing the pair of inner spurs. $C, D, E, F$, Transverse sections of the floral bud at four ascending levels. $S_{2}$ indicates the dorsal sepal, second in the initiation sequence. Green arrowheads indicate the fusion between adjacent dorsal petals. Note the inner spurs $(C, D)$, the shared cavity at the entrance of the spurs and the hollow depression on the dorsolateral petals $(E, F)$. $G, H$, Magnified views of one dorsal and one dorsolateral petal. Secretory tissues (large cells colored in red) are located at the floor of the shared cavity and on the walls of the hollow depression, respectively. Scale bars: F, $50 \mu \mathrm{m}$; E, $100 \mu \mathrm{m}$; A, B, $200 \mu \mathrm{m}$; C, D, G, H, 500 $\mu \mathrm{m}$.

Fig. 5 Disparity of the Delphinieae hyperorgan in a phylogenetic context and developmental pathway possibly explaining the morphogenesis of each of the types of hyperorgan. The wellsupported topology synthesizes our current knowledge about phylogenetic relationships in Delphinieae (Jabbour and Renner 2011b, 2012b; Wang et al. 2013; Espinosa et al. 2017; Hong et al. 2017; Xiang et al. 2017; Zhai et al. 2019). The type of hyperorgan is indicated in the black boxes. Genera and subgenera are specified in the grey text boxes. Within the spurred or hooded dorsal sepal (purple), the dorsalmost petals (green) present a shared cavity, or are borne on long stalks, or are totally fused. Color codes for the developmental pathway: Calyx: light blue: undifferentiated petaloid sepal, purple: dorsal sepal, light green: lateral sepal, mauve: ventral sepal. Corolla: orange: underdeveloped petal, red: developing petal, blue: undifferentiated nectariferous petal, light green: dorsolateral petal, dark green: spurred 
and nectariferous dorsal petal. Basally (and facultative) and totally fused organs are joined with thin and thick links, respectively. Yellow: androecium. Pink: gynoecium. 


\section{Supplementary figures}

Suppl. Fig. 1 Herbarium specimens of Delphinium including an illustration showing that dorsalmost petals are notched and basally fused (scar indicated by the green arrow), and that a scale can be found at the base of dorsolateral petals (red arrow). A, specimen of $D$. likiangense Franch., barcode P00198675. B, type specimen of D. souliei Franch., P00201009. $C, D$, Magnification of a portion of the illustration from $A$ and $B$, respectively. Highresolution images of the specimens can be accessed using the link: https://science.mnhn.fr/institution/mnhn/collection/p/item/search.

Suppl. Fig. 2 Flower of D. leroyi photographed on the Nyika Plateau, Malawi, in May 2019. $A$, Lateral view of the flower. The inner spurs can be distinguished by holding the outer spur against the light. $B$, Same flower, with all perianth organs removed, except one dorsal petal. Two beetles from the same species were found at the bottom of the shared cavity. $C$, Folding and compressing the inner spur results in a droplet of nectar forming at the bottom of the shared cavity. One beetle is in contact with this droplet of nectar. Scale bars: A, B, C, $1 \mathrm{~cm}$. Photograph credits: Florian Jabbour.

Suppl. Fig. 3 The floral parlor of Delphinieae flowers, composed of the cup-like shaped calyx, from the widest to the narrowest. Herbarium specimens were trans-illuminated to reveal the structures hidden in the dorsal sepal. A, Aconitum ambiguum Rchb., barcode P00601133. B, A. macrorhynchum Turcz., P00201813. C, A. sinomontanum Nakai, P00201961. D, Delphinium anthoroideum Boiss., P00195782. E, D. macrocentrum Oliv., P02379750. F, D. nanum DC., P02819166. High-resolution images of the specimens can be accessed using the link: https://science.mnhn.fr/institution/mnhn/collection/p/item/search. 


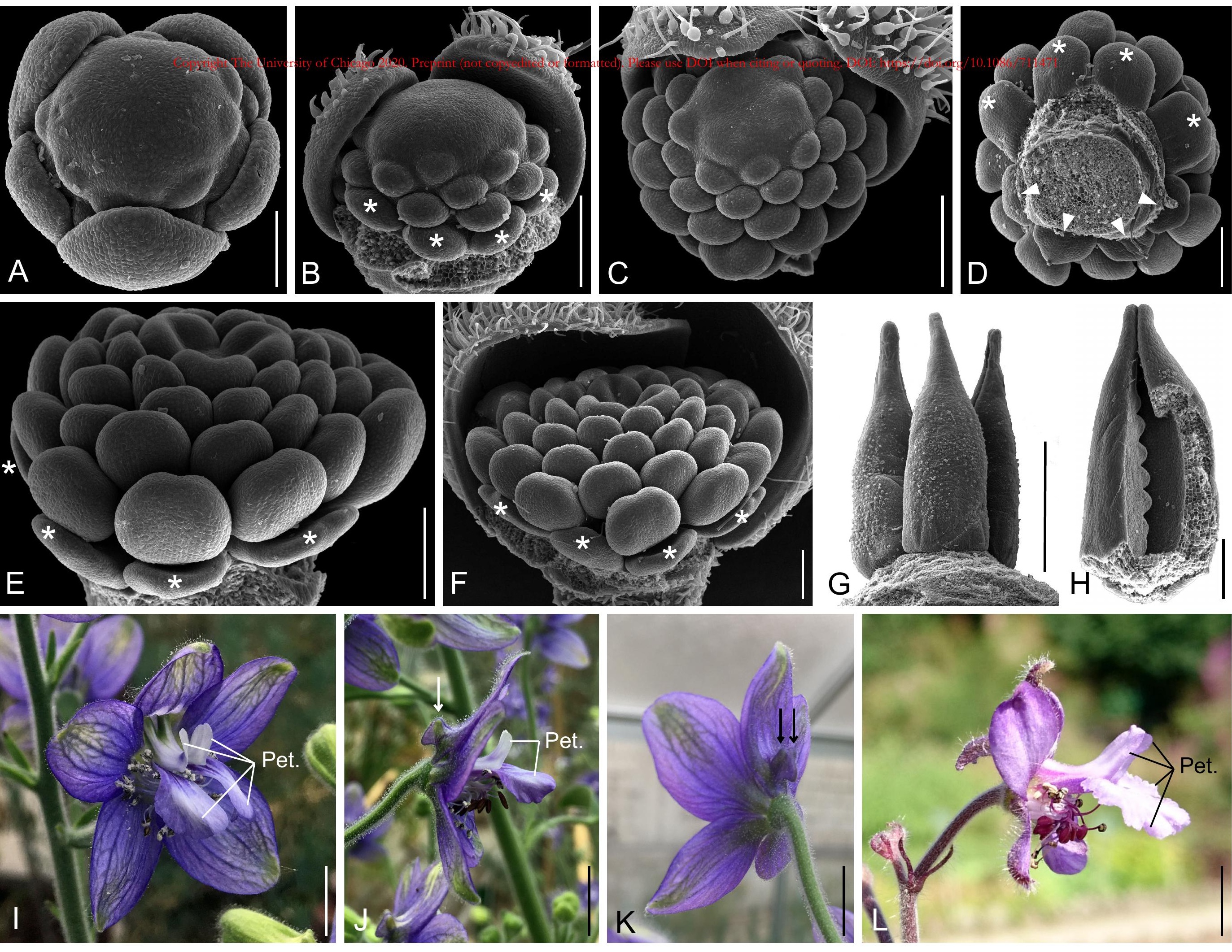








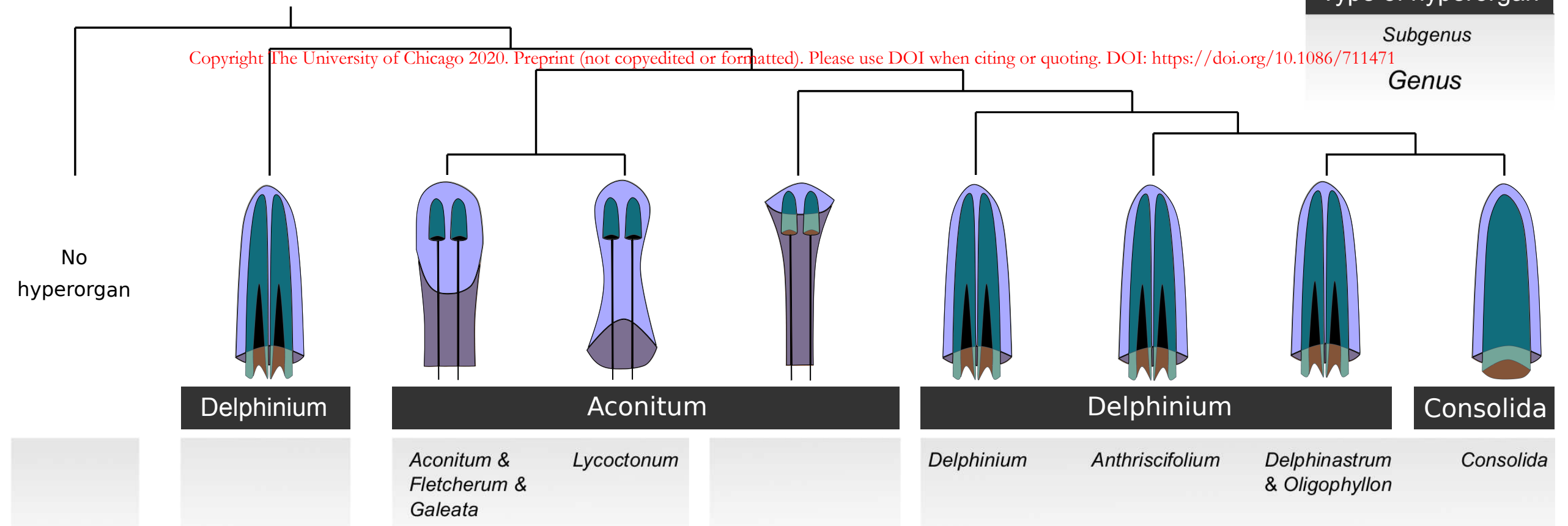

Nigella Staphisagria

Aconitum

Gymnaconitum

Delphinium
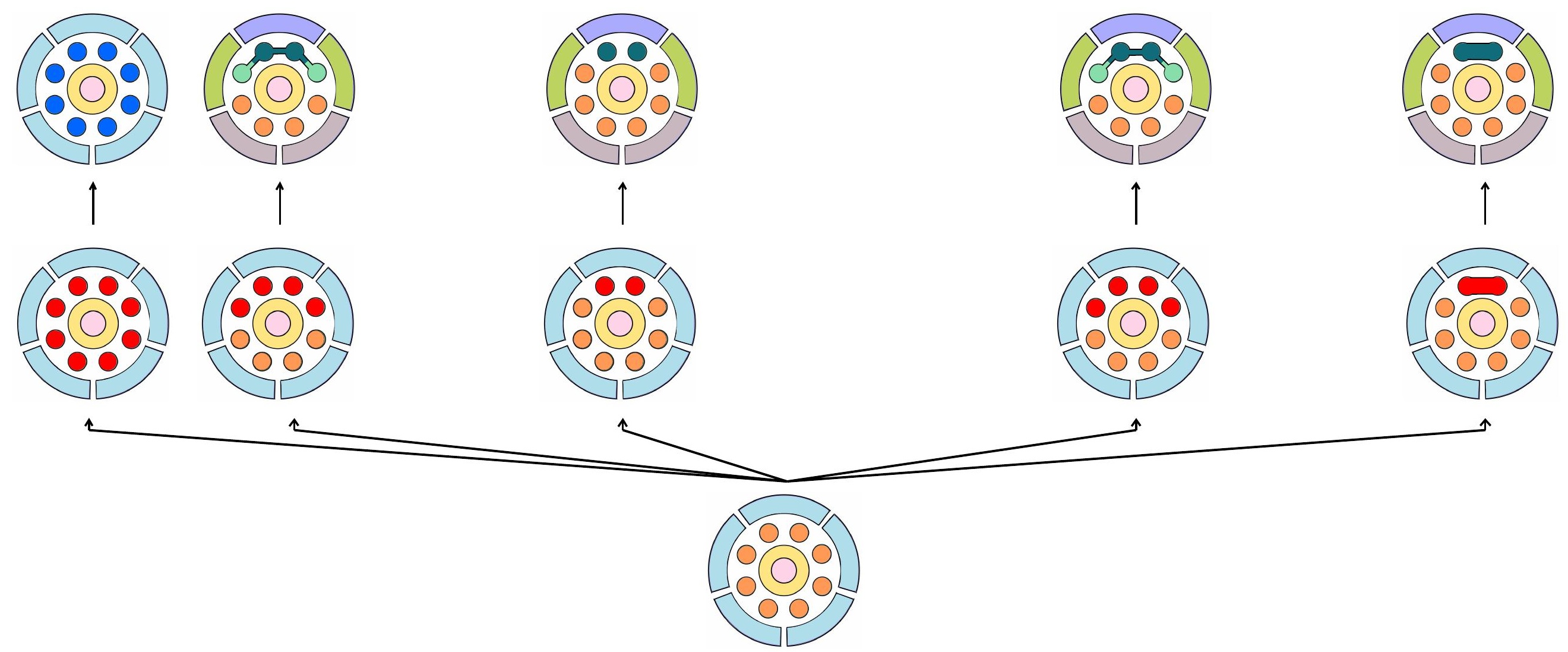

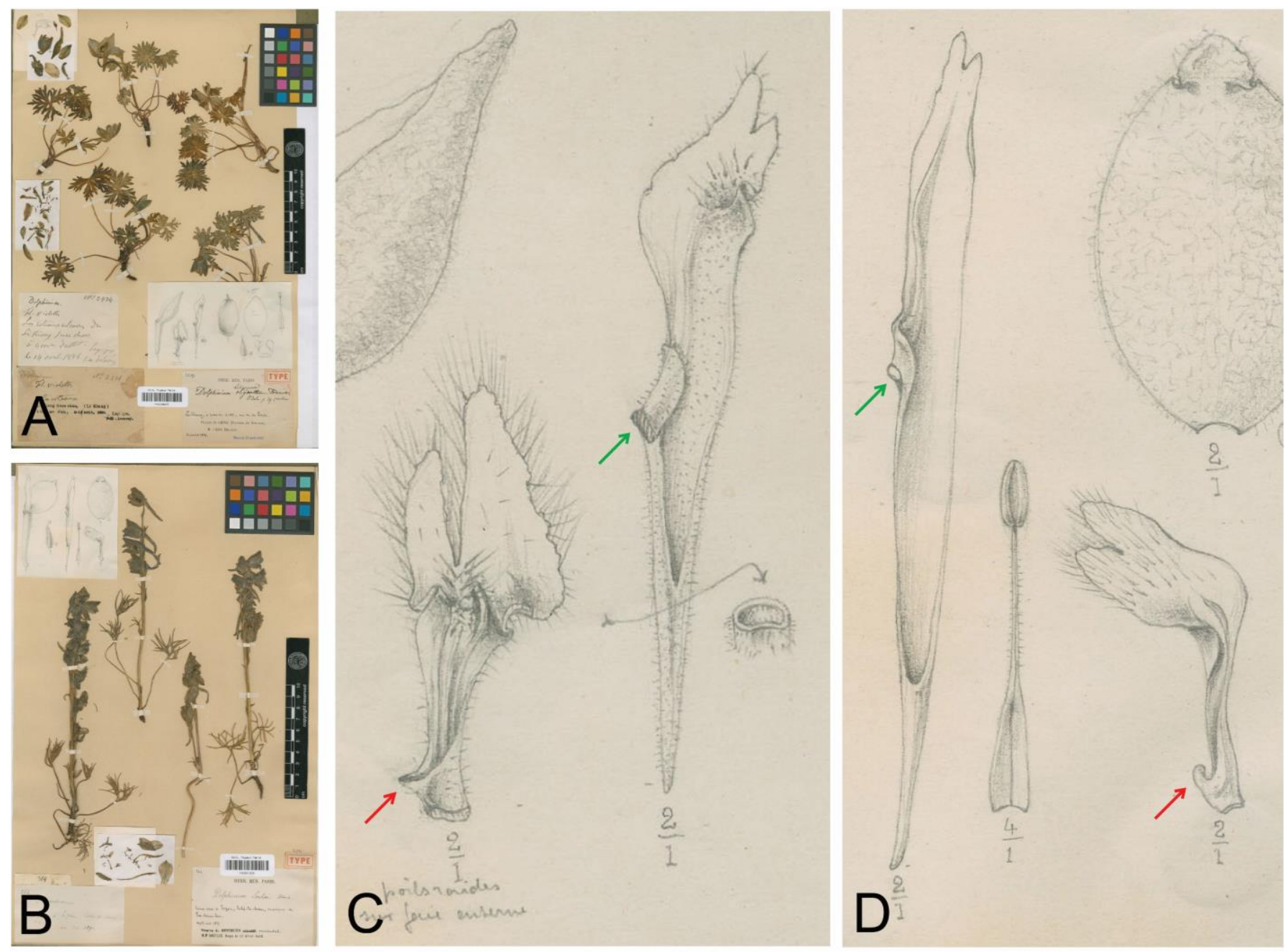

Suppl. Fig. 1 Herbarium specimens of Delphinium including an illustration showing that dorsalmost petals are notched and basally fused (scar indicated by the green arrow), and that a scale can be found at the base of dorsolateral petals (red arrow). A, specimen of D. likiangense Franch., barcode P00198675. B, type specimen of D. souliei Franch., P00201009. C, D, Magnification of a portion of the illustration from $A$ and $B$, respectively. High-resolution images of the specimens can be accessed using the link:

https://science.mnhn.fr/institution/mnhn/collection/p/item/search. 


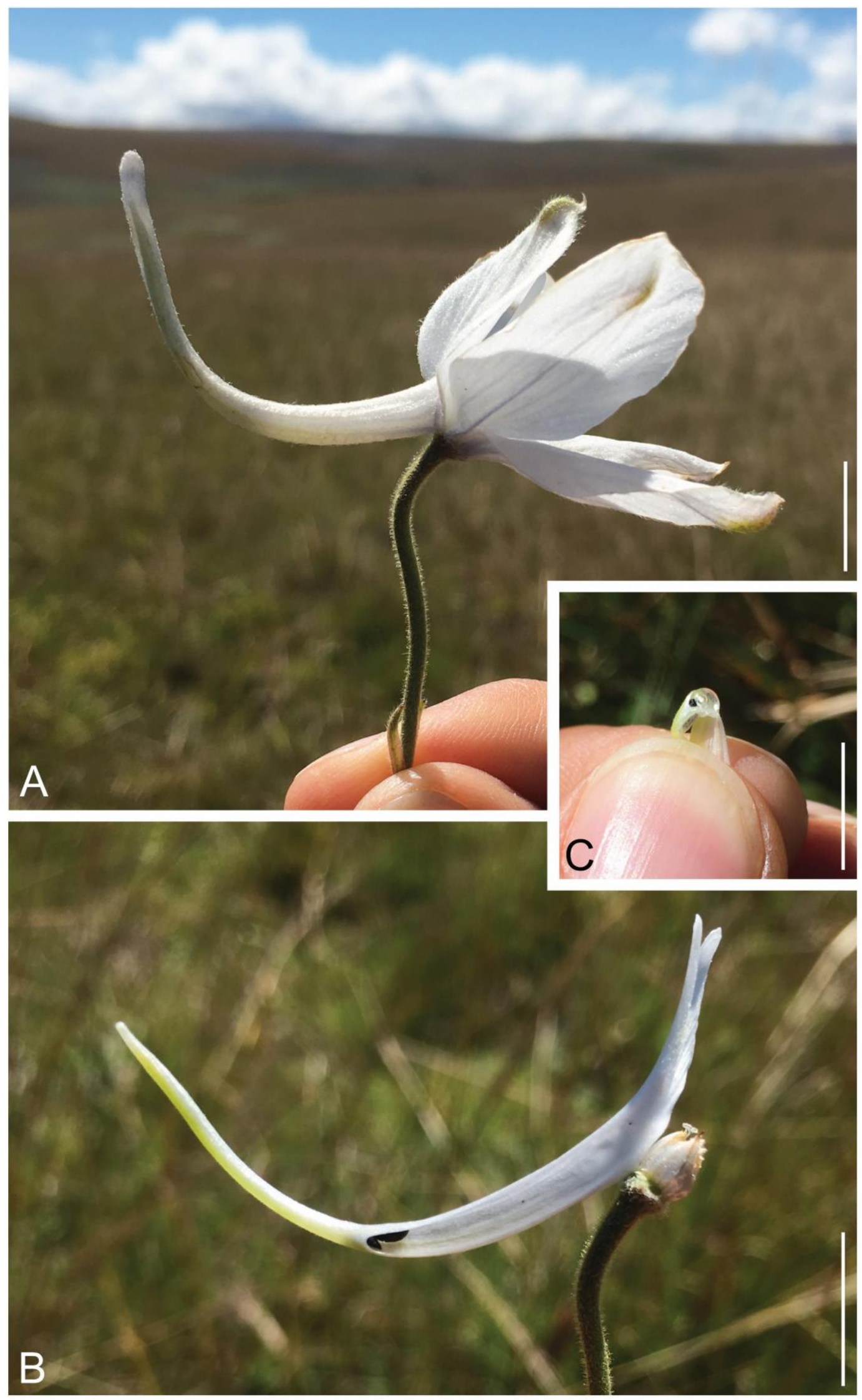

Suppl. Fig. 2 Flower of D. leroyi photographed on the Nyika Plateau, Malawi, in May 2019. A, Lateral view of the flower. The inner spurs can be distinguished by holding the outer spur against the light. $B$, Same flower, with all perianth organs removed, except one dorsal petal. Two beetles from the same species were found at the bottom of the shared cavity. $C$, Folding and compressing the inner spur results in a droplet of nectar forming at the bottom of the shared cavity. One beetle is in contact with this droplet of nectar. Scale bars: A, B, C, $1 \mathrm{~cm}$. Photograph credits: Florian Jabbour. 

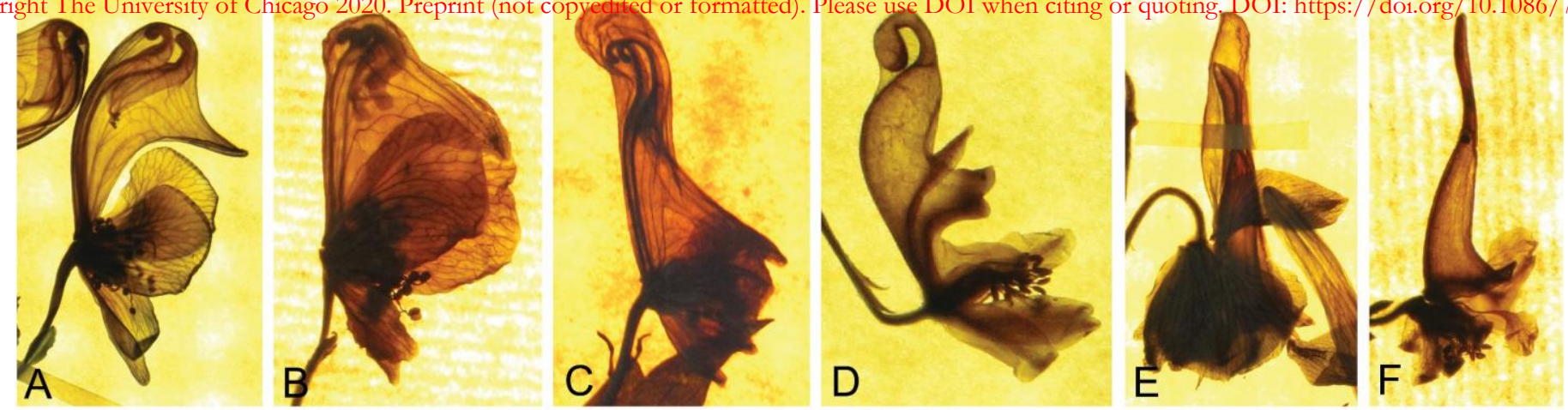

Suppl. Fig. 3 The floral parlor of Delphinieae flowers, composed of the cup-like shaped calyx, from the widest to the narrowest. Herbarium specimens were trans-illuminated to reveal the structures hidden in the dorsal sepal. A, Aconitum ambiguum Rchb., barcode P00601133. B, A. macrorhynchum Turcz., P00201813. C, A. sinomontanum Nakai, P00201961. D, Delphinium anthoroideum Boiss., P00195782. E, D. macrocentrum Oliv., P02379750. F, D. nanum DC., P02819166. High-resolution images of the specimens can be accessed using the link: https://science.mnhn.fr/institution/mnhn/collection/p/item/search. 